\title{
Job Satisfaction Among Primary Health Care Workers In Three Selected Local Government Areas In Southwest Nigeria
}

\author{
* O. E. Amoran MBBS, MMPsy, MSc, FMCPH, * F.O. Omokhodion PhD, FWACP, \\ * M.D Dairo MBBS, MSc, FMCPH, ** A.O. Adebayo PhD. \\ Departments of ${ }^{*}$ Community Medicine, University College hospital, Ibadan, and \\ ${ }^{* *}$ Psychology, Faculty of Social Sciences, University of Ibadan, Nigeria.
}

\begin{abstract}
Background: The primary health care system in Nigeria has been impaired by lack of dedicated workers who are willing to work in the rural areas. This study was carried out to examine factors that enhance job satisfaction among health workers in the primary health care system in Nigeria.

Method: The study is a cross-sectional descriptive study conducted in May 2002. The respondents were selected from three local government areas in southwest Nigeria by multistage sampling technique. A standardized structured pre-coded close-ended selfadministered questionnaire to collect relevant information on their socio-demographic characteristics and extent of job satisfaction of respondents.
\end{abstract}

Result: A total of 125 health workers were interviewed in all. The mean score on job satisfaction was 26.15 out of the total possible score of 49 . There was no statistically significant relationship in job satisfaction among the various cadres of health workers considered $(p=0.824)$. A larger proportion (66.4\%) of the health workers were involved with the community based preventive services when compared with the health centre based curative care $33.4 \% \quad(p<0.05)$, there is however no significant difference in satisfaction between this two groups of personnel $(p=0.133)$. Age and marital status were found to be statistically significant in relation to job satisfaction ( $p=0.000$ and 0.034 respectively).

Conclusion: The study shows no significant difference in job satisfaction among the various cadres of health workers in southwest Nigeria. However age and marital status were found to be significant factors influencing job satisfaction among the primary health care workers in Nigeria.

KEY WORDS: Job satisfaction; Job characteristics; Health workers; Primary health care.

Paper accepted for publication 14th January 2005

\section{INTRODUCTION}

The primary health care system in Nigeria has been hampered by the lack of dedicated personnel that will work in the rural areas. The effect of this had been poor mortality and morbidity indicators and poor health care in general. This had made it difficult for the smooth running of the health care system in Nigeria. This was what led to the creation of all other cadre of workers apart from the doctors and the nurses in the Nigerian primary health care system $^{1,2}$. Nigeria is undergoing a significant crisis in the health sector, as a result of incessant strikes. Workers in the health sector who have not been getting involved in these frequent protests are now joining other government workers to demand for extrinsic motivation in form of salaries, good working environment etc. This has resulted into a change in the attitude of the health workers to their job and had reduced the public respect for the health sector in general. It has been advocated that the characteristics of job enrichment will determine directly or indirectly the level of motivation to work thereby influencing job satisfaction and quality of working life of the workers ${ }^{3}$.

Two major approaches to job design that has been identified to improve job performance. These are the job enrichment approaches that attempt to make the jobs more interesting and challenging thus improving job satisfaction. This method facilitates good human relation and leadership and achieve organizational goal with minimal organizational conflict. Another major approach is the job engineering approach, which attempt to make jobs more 
efficient by improving work methods, tools and good structure. Such activities such as strict time management, provision of good and appropriate equipments and good settings are used to inspire workers to achieve their maximum potentials ${ }^{4-6}$.

Issues concerning job satisfaction of workers are of central importance in Health management. The management of most organizations are always interested in getting a true reason why a worker who apparently has the ability to do a job well consistently fail to perform effectively ${ }^{7,8}$. Moreover given the peculiar nature of primary health care which is basically carried out at the grassroots level, factors such as the willingness of the health workers to go to the rural areas to work is essential to its successful implementation. This study was therefore designed to determine the factors that are affecting job satisfaction among health workers in Nigeria.

\section{MATERIALS AND METHODS}

The study is a descriptive cross-sectional study conducted in May 2002. The respondents were selected from three local government areas in southwest Nigeria by multistage sampling technique. The southwestern part of Nigeria consists of six states namely Oyo, Ogun, Ondo, Ekiti, Osun and Lagos States out of which three were randomly selected for the study. One local government area each was then randomly selected from each of these states. The local government areas selected included Ibadan south east, LGA, Ise Ekiti in Ekiti State and Ogun waterside in Ogun State. The majority of the inhabitants were from Yoruba speaking tribe. It is the most developed and industrialized zone in Nigeria. The target population for this study was the health workers in the primary health care settings. These included the Environmental health officers, the pharmacy technicians, the community health extension workers (CHEWS) and community health officers ( $\mathrm{CHO}$ ) grouped together as Community health workers, Medical doctors and Nurses working in the health centres. Every health worker in these primary health care settings that were available at the time were given a standardized structured precoded close-ended self-administered questionnaire to complete.

The structured questionnaire had been pretested in a similar setting in a local government area in lbadan. The questionnaire sought information on age, sex, level of professional training, cadre of participants and other socioeconomic characteristics of the workers. The second part of this questionnaire contained items relating to job satisfaction such as depth of love for the present job, decision to change job, comparing satisfaction derived from job by the respondent with others in same profession and those in other occupation as originally designed by Hippock ${ }^{9}$. The questionnaire ranged from a 2-point to 7-point scale with 9 items in all. The total score possible was 49 for job satisfaction scale and the mean score for the respondent in this study was $25.96(S D=5.65)$. The mean scores were used to classify respondents into high satisfaction and low satisfaction.

Data were entered into the computer using the statistical programme SPSS software for data entry and analysis. Simple descriptive statistics of importance were produced. Association between two variables was sought using the Chi square test and student t- test of significance.

\section{RESULTS}

A total of 125 respondents were interviewed. Table I shows the socio-demographic characteristics of respondents in the study sample by age, sex and marital status. The age ranges between 25 and 52 years, and the mean age was $33.5(S D=1.25)$. Up to $41.6 \%$ were males and $58.4 \%$ were females. Majority $79.2 \%$ were married, $18.4 \%$ were single and $2.4 \%$ were separated. About $2.4 \%$ of respondent were medical doctors, $44.8 \%$ were Community health workers, $12.0 \%$ were Nurses, $31.2 \%$ were Environmental officers and $9.6 \%$ were pharmacy technicians. Furthermore $33.6 \%$ of the respondents described their job as health center based curative services while 66.4\% described their job as mainly community based preventive services such as environmental 
health supervision, immunization, etc.

There is a significant relationship between age and worker's satisfaction however the mean satisfaction score increased as the age increased $(p<0.00009)$. The proportion of female with high score on job satisfaction $(58.4 \%)$ was more than those of male workers $(41.6 \%)$. The mean score was however not statistically significant different $(p=0.344)$. All $(100 \%)$ of those separated from their spouses scored high on job satisfaction scale when compared to those married $43.4 \%$ and those that were never married $65.2 \%$. The difference was statistically significant $(\mathrm{p}<0.05)$.

A significantly higher proportion of the health personnel $(66.4 \%)$ described their jobs mainly as community based preventive services when compared with those who described theirs as health centre based curative services (33.4\%). There is however no statistically significant difference in job satisfaction between these two groups of personnel $(p=0.133)$. Furthermore the longer the years of experience on the job the more satisfied the workers become $(p=0.48)$. This is illustrated in Table II.

There is no statistically significant association between the cadre of health personnel and their job satisfaction $(t=0.37$, $\mathrm{p}=0.824$ ). The nurses had the highest mean score of 27.14 and the lowest by pharmacy technicians (24.15). Community health workers, Environmental health workers and the Medical doctors had 26.16, 26.32 and 25.67 respectively.

Table I. Respondent Characteristics by job satisfaction

\begin{tabular}{lllll}
\hline & $\begin{array}{l}\text { Total } \\
\text { Respondents } \\
\text { No (\%) }\end{array}$ & $\begin{array}{l}\text { Proportion } \\
\text { Satisfied } \\
\text { No }(\%)\end{array}$ & $\begin{array}{l}\text { Mean Score } \\
\text { (S.D) }\end{array}$ \\
\hline Age in years & & High & Low & \\
25 and below & $11(8.8)$ & $9(7.2)$ & $2(1.6)$ & $27.45(7.29)$ \\
$26-30$ & $16(12.8)$ & $9(7.2)$ & $7(5.6)$ & $27.60(4.36)$ \\
$31-35$ & $25(20.0)$ & $16(12.8)$ & $9(7.2)$ & $29.15(3.53)$ \\
$36-40$ & $40(32.0)$ & $6(4.8)$ & $34(27.2)$ & $23.32(5.38)$ \\
$41 \&$ above & $33(26.4)$ & $21(16.8)$ & $12(9.6)$ & $27.81(4.47)$ \\
Total & $125(100)$ & $61(48.8)$ & $64(51.2)$ & $26.32(5.41)$ \\
Sex & & & & \\
Male & $52(41.6)$ & $23(18.4)$ & $29(23.2)$ & $25.57(5.67)$ \\
Female & $73(58.4)$ & $38(30.4)$ & $35(28.0)$ & $26.56(5.53)$ \\
Total & $125(100)$ & $61(48.8)$ & $64(51.2)$ & $26.15(5.59)$ \\
Marital Status & & & & \\
Single & $23(18.4)$ & $15(12.0)$ & $8(6.4)$ & $27.87(5.83)$ \\
Married & $99(79.2)$ & $43(34.4)$ & $56(44.8)$ & $25.52(5.42)$ \\
Separated & $3(2.4)$ & $3(2.4)$ & $0(0.0)$ & $32.67(1.53)$ \\
& $125(100.0)$ & $61(48.8)$ & $64(51.2)$ & $26.15(5.59)$ \\
\hline
\end{tabular}

Age $x^{2}=28.66 p=0.000$ Sex $\chi^{2}=0.74 p=0.388$ Marital status $\chi^{2}=6.77 p=0.034$
Table II. Job description and Satisfaction

\begin{tabular}{|c|c|c|c|c|}
\hline Job description & $\begin{array}{l}\text { Total Respo } \\
\text {-ndents } \\
\text { No (\%) }\end{array}$ & $\begin{array}{l}\text { Proportion } \\
\text { Satisfied } \\
\text { No (\%) }\end{array}$ & & $\begin{array}{l}\text { Mean Scores } \\
\text { (S.D) }\end{array}$ \\
\hline & & High & Low & \\
\hline Curative Services & $42(33.6)$ & $21(16.8)$ & $21(16.8)$ & $26.35(5.95)$ \\
\hline Preventive Services & $83(66.4)$ & $40(32.0)$ & $43(34.4)$ & $26.05(5.44)$ \\
\hline Tot al & $125(100.0)$ & $61(48.8)$ & $64(51.2)$ & $26.15(5.59)$ \\
\hline \multicolumn{5}{|l|}{ Years of Experience } \\
\hline $0-10$ years and below & $113(90.4)$ & 54 (43.2) & $59(47.2)$ & $25.99(5.45)$ \\
\hline 11 - 20 years & $12(9.6)$ & $7(5.6)$ & $5(4.0)$ & $27.73(6.89)$ \\
\hline Total & $125(100.0)$ & $61(48.8)$ & $64(51.2)$ & $26.15(5.59)$ \\
\hline
\end{tabular}

Job description $x^{2}=2.26 \quad p=0.133$ Years of experience $x^{2}=0.48 \quad p=0.487$

Table III. Job satisfaction among health personnel

\begin{tabular}{|c|c|c|c|}
\hline $\begin{array}{l}\text { Cadre of health } \\
\text { personnel }\end{array}$ & $\begin{array}{l}\text { Total Respondents } \\
\text { No }(\%)\end{array}$ & $\begin{array}{l}\text { Proportion } \\
\text { Satisfied No (\%) }\end{array}$ & \\
\hline & & High & Low \\
\hline $\begin{array}{l}\text { Medical } \\
\text { practitioners }\end{array}$ & $3(2.4)$ & $1(0.8)$ & $2(1.6)$ \\
\hline $\begin{array}{l}\text { Pharmacy } \\
\text { technicians }\end{array}$ & $12(9.6)$ & $5(4.0)$ & $7(5.6)$ \\
\hline $\begin{array}{l}\text { Community } \\
\text { health workers }\end{array}$ & $56(44.8)$ & $26(20.8)$ & $30(24.0)$ \\
\hline Nurses & $15(12.0)$ & $9(7.2)$ & $6(4.8)$ \\
\hline $\begin{array}{l}\text { Environmental } \\
\text { health officers }\end{array}$ & $39(31.2)$ & $20(16.0)$ & $19(15.2)$ \\
\hline Total & $125(100.0)$ & $61(48.8)$ & $64(51.2)$ \\
\hline
\end{tabular}

\section{Table IV. Mean Score by Cadre personnel}

\begin{tabular}{lll}
\hline $\begin{array}{l}\text { Cadre of health } \\
\text { personnel }\end{array}$ & $\begin{array}{l}\text { Total Respondents } \\
\text { No }(\%)\end{array}$ & $\begin{array}{l}\text { Mean Score } \\
\text { (S.D) }\end{array}$ \\
\hline $\begin{array}{l}\text { Medical } \\
\text { practitioners }\end{array}$ & $3(2.4)$ & $25.67(5.51)$ \\
$\begin{array}{l}\text { Pharmacy } \\
\text { technicians }\end{array}$ & $12(9.6)$ & $24.50(6.04)$ \\
$\begin{array}{l}\text { Community } \\
\text { health workers } \\
\text { Nurses }\end{array}$ & $56(44.8)$ & $26.16(6.57)$ \\
$\begin{array}{l}\text { Environmental } \\
\text { health officers }\end{array}$ & $15(12.0)$ & $27.14(4.11)$ \\
\hline Total & $125(100.0)$ & $26.32(4.47)$ \\
\hline
\end{tabular}

$F=0.1369, \quad p=0.824$

\section{DISCUSSION}

The mean score of 26.15 out of the maximum score of 49 is quite low thus indicating a generally low level of satisfaction being experienced among the different cadre of personnel involved in the primary health care 
delivery in Nigeria. Prompt attention should be paid to workers' welfare in order to increase performance and reduce workers' turnover. This will increase the efficient and smooth running of the primary health care system in Nigeria ${ }^{10,11}$.

Marital status was found to be a significant factor that affects job satisfaction among these health workers, those that are single were found to be more satified with their job when compared with those that were married. The need for more income to maintain the family may be responsible for the pressure on the health workers. This can be further buttressed by the fact that those that were separated from their spouses were found to be more satisfied than when compared with both the workers who were single and those married. This may be attributed to the present economic situation of poverty in Nigeria. The fact that female had a higher score on job satisfaction though not statistically significant is worth mentioning; this fact has been reported in recent studies on job satisfaction among health workers ${ }^{12}$. However age was found to be a significant determinant of job satisfaction higher proportion among the younger health workers were found to be satisfied with their job compared to older workers. This has a grave implication in personnel recruitment. The same conclusion has been made in other similar studies ${ }^{4,13}$.

The finding that there is no significant relationship between the cadre of health personnel and job satisfaction implies that job satisfaction among these personnel depended on other factors other than occupation. Further research work needs to be done in these areas. However those who have spent longer years of working experience (>10 years) in employment were found to be more satisfied with their jobs. This suggests that job satisfaction among these health workers depends on their adapation to their work environment. This have been found to be true in several studies where job satisfaction was best predicted by a longer duration of working experience and high levels of self-efficacy, personal accomplishment, and perceived benefit ${ }^{14-16}$. For this reason frequent transfer and relocation should be avoided in the management of the health care delivery in Nigeria.

The study shows that job satisfaction among the health workers in Nigeria depends on the income and the adaptation to their work environment. Moreover emphasis in health care at the primary level is being shifted towards preventive care rather than curative care.

\section{REFERENCES}

1. Federal Ministry of Health. The National health policy and strategy to achieve health for all Nigerians. Lagos 1988.

2. Shodeinde $O A(e d)$. Primary health care in Nigeria our children can now live. Lagos: Emancipation consultants and publishers, 1982.

3. Hackman SR, Oldham GB. Job characteristics and intrinsic motivation: The moderating effect of interpersonal and individual variables. Human Relations 1976; 29 (6): 559-570.

4. Lawrence PR, Runner AN. Industrial jobs and the worker: An Investigation of response to task attributes. Boston: Harvard University graduate school of Business administration, 1965.

5. Rewn A. Holistic evaluation of the job. Dissertation Abstract International 1990; 50 (7): 2154-2155.

6. Oldham GB, Hackman SR, Pearce JL. Conditions under which employees respond positively to enriched work. Journals of Applied Psychology 1976; 61(4): 395-396.

7. Standard KC. Health planning and administration. In: Cruishan. R, Standard KL, Russel HBL (eds). Epidemiology and Community health in warm climate countries. Edinburgh: Churchill Livingstone, 1976.

8. McNaught A. Measurement and management in medicine and health services, training needs and opportunities. New York: Rockefelle Foundation, 1985.

9. Hippock R.(Ed). Job satisfaction. New York: Harper and Row Publishers, 1935: 250-252.

10. Bonnie S, Chris B, Hugh G. National survey of job satisfaction and referent intentions among general practitioners in England. BMJ 2002; 3(5): 10-11.

11. Womons JP. Who wants job Enrichment? Advanced Management Journal 1976; 41 (3): 15-22.

12. Jinapriya D, Cockerill R, Trope G E. Career satisfaction and surgical practice patterns among female ophthalmologists. Can J Ophthalmol 2003; 38(5): 373-378.

13. Yan EC, Tang CS. The role of individual, interpersonal, and organizational factors in mitigating burnout among elderly Chinese volunteers. Int J Geriatr Psychiatry 2003; 18(9): 795-802.

14. Machungwgwa PD. Work Motivation in Zambia: an exploratory study. Dissertation Abstract International 1981; 42(8): 3478-3479.

15. Al-Mashaan OS. Associations among job 
Job Satisfaction Among PHC Workers - O.E. Amoran, F.O. Omokhodion, M.D. Dairo, A.O. Adebayo

satisfaction, optimism, pessimism, and psychosomatic symptoms for employees in the government sector in Kuwait. Psychol Rep 2003; 93(1): 17-25.
16. Monga M, Doyle NM, Campbell D, Promecene PA, Schneider KM. Job satisfaction among program directors in Obstetrics and Gynaecology: a National portrait. Am J Obstet Gynecol 2003; 189(3): 628-630. 